\title{
THEORETICAL AND EMPIRICAL FOUNDATION FOR INTEGRATION OF LANGUAGE EDUCATION IN CLASSES OF OTHER DISCIPLINES
}

\author{
Daiva Jakavonytė-Staškuvienė ${ }^{1}$
}

\begin{abstract}
Recently, Lithuania and other European Union member states experienced a marked deterioration of pupils' linguistic skills (especially reading and writing), according to data from the 2006 and 2011 Progress in International Reading Literacy Study. This article analyzes the possibilities of integrating the education of linguistic skills into classes of other disciplines, in terms of the planning and organization of integrated linguistic education, how to begin, and what to expect. To solve these issues, the experience of such matters in Switzerland was studied by analyzing the results of qualitative research.
\end{abstract}

UDC Classification: 37.02, DOI: http://dx.doi.org/10.12955/cbup.v4.811

Keywords: language, integration, discipline, didactics.

\section{Introduction}

In considering languages and didactics, it is important to understand the concurrency of language policy and culture in dimensions of methodology, programs, and the pupils' expected learning outcomes (knowledge and comprehension, skills, and value-based attitudes). These are central issues that need consideration in documents regulating a language curriculum (Puren, 2003; Borg, 2013). In the opinion of Beacco (2013), the issue of integrated didactics is "alive" if it is unanimously agreed upon at all levels.

The main factors that lead to success of this idea are policy, ethics, professionalism, responsibility, rights, and duties. Quality integrated language education is only possible with dialogism of cultures and a change in teaching and learning culture (constant renewal) that are ensured by triangular methodology (qualitative methods, comprehension, and constructivism), targeted education programs (pragmatic and complex attitude), and embracing culture and its cognition in both local and global contexts.

The objective of this research is to analyze the possibilities of integrating language education into classes of other disciplines.

The tasks of the research are as follows:

1. To provide theoretical background for the didactics of integrating language education in classes of other disciplines; and

2. To describe the results of qualitative research, i.e., the Swiss experience of applying integrated language didactics with a discussion of advantages and organizational difficulties.

The language integration policy of the European Union directive is a constant topic in public discussions, and thus, of social importance. The discussions attempt to answer various questions of how to implement related policies as satisfactorily as possible (Beacco, 2008; Maurer, 2011; Abdallah, 2013; Castellotti, 2013; Belhadj Hacen, 2013). The White Paper of the Council of Europe (2008) emphasized that intercultural dialogue was an open and respectful process between people and groups of different origin, traditions, and of ethnic, cultural, religious and linguistic skills. In addition, such dialogue requires an exchange of opinions with an understanding based on mutual respect.

Essential elements include the freedom and opportunity to express oneself and a willingness and ability to listen to others. The Council of Europe aims to promote the language policy in the following areas:

\footnotetext{
${ }^{1}$ Daiva Jakavonytė-Staškuvienè, Institute of Educational Research, Lithuanian University of Educational Sciences, Lithuania, daiva.jakavonyte@leu.lt
} 
- Multilingualism; all citizens of the European Union have the right to improve the level of communication competence in several languages and seek a lifelong improvement of this according to their needs;

- Language diversity; Europe is multilingual and all of its languages are of equal value and importance as a means of communication, expression, and identity. Conventions of the Council of Europe ensure the right to learn languages; and

- Mutual understanding; intercultural communication and acceptance of cultural differences support the ability of learning other languages.

According to Beacco $(2008,2013)$, multilingualism is the key principle of the Council of Europe aimed at encouraging the learning of languages. The choice of multilingualism is also clearly expressed by Maurer (2011), who wrote that since the 18th century until somewhat recently a person's identity and identification papers were based on language and culture, whereas in today's society, a person's identity is related to the diversity of linguistic and cultural interaction and identification forms need to correspond. While this provision is embedded in several documents of the Council of Europe, its implementation is reliant on the policy makers of individual countries. However, multilingualism in Europe, in research terms, is understood, not as a "multitude of languages", but as a consciousness, and the competence of knowing linguistic differences is related to the experience of learners. This position encourages competence and qualification of multilingualism, referred to as the "Copernican Revolution" (Blanchet, 2007) or a revolution in education didactics where the cognition of cultures is underlined (Hagège 2005; Coste, 2008; Benaicha \& Legros, 2009; Blanchet, 2010). It will never, however, mean "to make a school" without focusing on the conception of education, the system of values, and the development and consequences of education (Coste, 2001, 2002a, 2002b, 2003, 2004; Moore \& Castellotti, 2008).

According to a number of researchers (Cortier \& Di Meglio, 2004; Belhadj Hacen \& Legros, 2009, 2010; Kroll, 2010), the influence of bilingualism and multilingualism in learning other disciplines (in interdisciplinary integration) is positive for the learning of other languages and the development of interdisciplinary knowledge and skills.

\section{Advantages of Bilingualism and Language Education Methods in Classes of Other Disciplines}

The methods of bilingual education can provide a student with an opportunity to understand another language and to develop their recall and cognitive and linguistic competences that enable them to interact (to communicate) with various individuals and become familiar with other cultures (to build cooperation in relationships). Linking multilingualism competence and education didactics in other disciplines with development and assessment of a language curriculum avails the following:

- A pluralistic society of linguistic phenomena that is influenced by historical and social circumstances (the status of inequality and power, the status of minority, creativity, the standards of education, and standardization processes);

- Competences (the unity of knowledge, skills, and attitudes) that are acquired in a differentiated and contextually adapted education system; and

- Social and cognitive diversity at the centre of education; recognizing a person's individuality and thus encouraging the development of multilingual competence (Moore \& Castellotti, 2008), which is the basis of multicultural diversity (De Pietro, 2003).

Increased awareness of the goals of mobility and education, the experience of languages, and cultural diversity, including partial awareness (typical of extremely innovative self-education area and modern learning of languages) circumvents the use of multilingualism as "a gun in the hands" of neoliberal ideology. Castellotti (2013) stressed that projects developing multilingual competence were weakened by a lack of specific explanations and the difference in illustration, clarity, and perception between research and research institutions. In addition, Chomentowski (2009a, 2009b), in his research, highlighted the problems of migrant children in learning language. He claimed that these children were discriminated against, not because of their country of origin, but because of their poor language skills, with schools unprepared and devoid of didactic instruments to identify a child's specific language ability and then apply particular methods to expand the child's language knowledge and skills. The 
reasons for such problems are various, including social, educational, and linguistic-cultural differences. A possible solution is compliance with a specific agreement containing clear examples, sharing advantageous experiences.

\section{Theories as the Basis for Integrated Language Education Didactics}

A constructivist attitude (cognition and metacognition) is a cognitive paradigm that has dominated the research area of linguistics, language teaching and learning, and cultural awareness (Cole, 1985; Lave \& Wenger, 1988; Rogoff, 1990; Chomentowski, 2009a, 2009b; Castellotti, 2013). According to this research, learning is focused on the cognition of a learner; this proceeds through constant cognition, building, rebuilding, and rediscovering various linguistic and cultural learning achievements. Linguistic competence develops along with cognitive skills (Hall, 1993; Mondada \& Pekarek, 2000, 2004; Lantolf, 2000). In learning and teaching, it is important to acknowledge attitudinal differences among individuals and that respecting these differences helps to avoid confrontation within the context of language and native cultures. The approach of constructivism is crucial when teaching languages in the crossroads of multilingual, educational, and cultural policy. For modern educational didactics it is highly significant to conduct research into educational methods that embrace teaching and learning traditions, teaching and learning environments, personal experience, psychological individual traits, and features of separate cultures.

Sociocultural theory involves tasks in class and social life. A change in paradigms is affected by the communicative approach of society. Since society often features mobility and intercultural cooperation, school life should be similar. Knowledge of innovative technologies requires linguistic competence. In discovering new forms of communication through cooperation in work, modern technologies are often encountered. Language is of major importance in ensuring cooperation between people of different cultures to achieve a common goal, for example, to inform, report, identify, verify, cancel, explain, justify, evaluate, argue, or make decisions using appropriate linguistic skills (Moirand \& Treguer-Felten, 2007). The parallel between society and the microclimate of the class should be mirrored in school curriculum by enhancing language positions and by turning school tasks into social activities. The task can be regarded as a learning activity and focus on life or a social perspective (Martinand, 1986; Lantolf \& Pavlenko, 1995; Puren, 2004; Bronckart, Bulea, Pouliot, 2005). This strategy involves a socio-communicative dimension, namely, a social-constructivist attitude.

Rationalization of language teaching and learning projects, according to Dolz, Rosat, and Schneuwly (1991), Dolz and Schneuwly (1997, 1998), Dolz and Thévenaz-Christen (2002), and Schubauer-Leoni and Dolz (2004), involve developing integrated language didactics aligned with the curriculum of other disciplines. It is necessary to adjust both the curriculum of the discipline and language development peculiarities to identify specific issues and spotlight problematic cases of both language and discipline that need consideration when organizing the curriculum. Difficult cases need analysis using several different methods and with proper consideration of those that lead to maximum progress of pupils. It is important to identify and develop the cognition system of various text genres, and discovers the most beneficial and targeted strategies; the application thereof helps children to master the curriculum in the most efficient and simplest way. With these strategies in mind, the curriculum is therefore shaped and designed on the pupils' learning outcomes and competences (of both integrated disciplines), with the strategies applied.

\section{The Development and Implementation of Integrated Language Didactics}

In the opinion of Brohy (2002), the success of bilingual education depends on the chosen model. It is important to choose topics that are interesting for children and which reflect the integrated development of linguistic, as well as social and other life skills. Those most favorable are general topics, such as, the forest and water. It is then possible to organize an integrated activity day or week, to develop various projects, or organize trips involving, not only certain knowledge, but also life skills that help build learning competences.

The topic should be chosen in such a way that pupils can look for authentic material in several languages and media (newspaper articles, scientific catalogues, online documents, discussions, roundtable discussions, and TV shows). This approach is an important component of bilingual education. To 
integrate language education into classes of other disciplines, one needs to discover the relationship between humanities and the physical sciences, for example, integrated perception of nature and culture. From another perspective, "green" or other topics of relevance today, are useful for language projects. More general interdisciplinary topics should be chosen, where every learner can find an interesting subject. Also, the possibilities to select such material should be considered; where it is possible to photograph objects and find information about the subject in the media, and either bring exhibits to school or visit such out of school (tours, camps, and school trips). The content should also cover the various programs to be integrated (for example, civic engagement and sustainable development). Family trips, meetings with representatives of companies, and visits to operations of companies are suitable to implement such goals.

The criteria for developing integrated content according to Brohy (2002), Brohy and Gajo (2008), and Gajo and Grobet (2011), include the following:

- A school's cultural situation;

- The level of pupils' linguistic skills;

- The amount of integrated curriculum (for example, $10 \%, 25 \%$, or $50 \%$ of integrated content) and the effect on the second language learning;

- The extent to which integrated curriculum is compulsory (in regard to schools, teachers, children; which part will be compulsory, and which part will be elective or non-formal);

- The range of disciplines, the content of which will be instructed in the second language;

- The continuity, interception, consistency, and sustainability of bilingual education (transferring from one educational program to another);

- The description of competences gained by pupils within integrated curriculum (both linguistic and discipline competences);

- Modes of delivery (whether it will be a class activity, a short-term project, or a long-term project, the flexibility of the schedule when the project is implemented by teachers of several disciplines, should encompass integration of classes, teachers' cooperation, and joint activities);

- Language integration (whether it will be one language and another discipline, two languages and another discipline, or more than two languages (multilingualism) and another discipline);

- The level of interaction (the extent to which information and communication technology is used among pupils of the class to communicate, and the extent to which pupils communicate with pupils from other countries); the cooperation helps pupils to read and understand texts in several languages, and to write letters in several languages;

- Cooperation between disciplines (language and other disciplines) and teachers (deciding on who performs the different roles, which subjects of the curriculum are integrated, and who assumes responsibility and in the different areas),

- teachers' training (the knowledge of the discipline and the second language) and mobility encouragement; and

- Informing the community about the idea of integrated education (whether it is compulsory or voluntary, its aims and expected results).

Depending on the logistics of organizing bilingual education (number of participants, the size of premises and space, and the application of audio and visual tools), it can involve countless configurations, and extra or fewer interactive ways and bi- or multilingual cases. It is recommended to pursue various ways of attaining set goals. The research into bilingual education shows that such education determines the development of analytical skills, as the basis of education is designed from the discourse and interaction of education participants, the interaction between language teaching and discipline learning; also the difficulties of bi- or multilingual interactions need consideration.

\section{Organization of Empirical Research}

Empirical research was performed June to August, 2014 at the University of Fribourg, Switzerland during an internship supervised by Prof. Dr. Gohard-Radenkovic. The Swiss scientists are especially advanced in terms of integrated language didactics. Languages are taught in an integrated way during the classes of all (or selected) science disciplines and the curriculum is organized in a way that pupils' 
linguistic skills and knowledge in their chosen discipline are developed integrally. A qualitative survey was conducted within the framework of the empirical research, and this was a semi-structured interview with Swiss experts of integrated language didactics with high theoretical and practical expertise in this area. The interviewees were three experts of integrated didactics; one was a researcher of multilingualism and integrated language didactics, the second a representative of a municipality where languages were taught in an integrated way, and the third a representative of a school where the curriculum was integrated with language being taught in the classes of other disciplines. Each interview was voice-recorded in French. This paper provides the responses of the interviewees that best reflected the research questions. These responses highlighted the peculiarities of integrating language education with other disciplines, the reasons behind choosing such didactics, and the organizational advantages and challenges. Due to article length restrictions, only a part of the material is provided.

\section{Analysis and Interpretation of the Results of the Empirical Research}

This research examined why schools choose certain bilingual or multilingual educational models and their models of learning languages in classes of other disciplines. The respondents of the research survey stated that the choice of a model depended on language diversity and the needs of the local community. In the opinion of the representative from a municipality where language is taught in an integrated way. Firstly, time needs to be allocated to analyse examples of good practice and only then to projects are to be developed in bilingual classes. It is responsible; the headmaster of the school discusses all issues related to bilingual projects with the city community, which wants to develop bilingual education.

Another respondent, a school representative spoke similarly of their language learning policy, emphasizing that language is a part of every person's identity, clear language learning policy in the school, it has had a positive effect on pupils' learning skills of the first language and other languages. Why? $<1$. We have determined that if a pupil works more with the skills of his/her native language by developing written language, especially a text, these skills improve when s/he is learning other languages. Therefore, instead of focusing only on the official language of instruction used in the school, we must not forget child's first (native) language as well; because this work helps to develop pupils' cognitive skills, which are of great significance when learning other disciplines in other areas. 2. We have determined that pupils' status changes according to the use of language, i.e. some pupils are very proud to speak their first language, while other can hide their identity because in a global world, in the $21^{\text {st }}$ century, it is more likely that trends are important, because politically and economically there are languages which are equalled to global languages, however, such thinking is a serious mistake. We think that every person has to know his/her identity, to take over family's cultural environment and traditions, to grow, to develop. 3. We emphasize that it is not enough to learn only English because this will lead to pupils being less creative, less innovative.>

The main models of integrated language didactics were discussed during the interviews. In the opinion of the researcher, integrated didactics covers several areas, for instance, integrated didactics of the bilingual education; another aspect is the integration of languages and other disciplines. There is French and English; French and German; German and French; Italian and French, Italian and German. This is bilingual education. There are also other models, like Polish, Russian, Bulgarian; there is a number of them. Three languages are compulsory in Swiss primary schools. There are a lot of discussions about integrated didactics, because Germans want German and English, but not French. They say there are too many languages in the primary school. Immigration is very strong in Switzerland. There are as many as twenty-five per cent of immigrants. Therefore, there are a lot of classes where the number of foreigners account for sixty, seventy, eighty per cent. This is too difficult for foreigners, because they have three languages in the primary school; besides, these are foreign languages for them, because they speak Portuguese, Spanish, Turkish, Albanian, Croatian, and Serbian at home. These are four or five languages in the primary school. Thus they say there is too much of all this. They say if there are three languages in the primary school, we have to integrate them. Integration is necessary between the second and the third language. For instance, German and English can be integrated; it is all right, because these languages are "cousins". The researchers pointed out the need to learn the language of the country where the child lives. The local language is also very important 
for us, because this is the language of work, studies, literacy and culture: <We have the language policy everywhere, we have everything, for instance, the European Charter for Regional and Minority Languages, they say everywhere that one needs to learn languages; including languages of the place where you live. These things are obligatory. Switzerland has four languages which are obligatory, however, there is no obligation (there is a possibility) to learn one's native language (in the case it is not the state language). You have a political level after the Soviets when you have to create your national identity. National identity can be created with your own language, of course. The Lithuanian language can be learnt in a bilingual way; this is the opportunity for all. The Russian language is also important, because Russia is an economic partner, besides; it is a Slavonic language, which enables commerce with Poland, the Czech Republic, Slovakia and other countries that speak Slavonic languages. It is obvious, but currently when you live in Lithuania learning Lithuanian is par for the course.> Languages can also be taught in an integrated way when they do not belong to the same family; strategies are necessary about how to start developing the vocabulary, what is effective for this type of cognition; how we learn, how we visualize, how we put it in words; how all that goes to your language biography (language baggage). These are the things which are important when learning the language of a different family. In Switzerland we have a specific integrated didactics, which helps to learn to understand languages and to of course speak, for instance, the German Switzerland has dialects, which are very different; we say one needs to learn to speak; because all languages have distinctive manners, besides, one needs to speak, not just to understand and write in any language. To summarize the results of the survey, language learning models and the selected strategies depend on the needs of the local community. This is based on the concept that a person with skills in multiple languages can integrate socially, not only in the country where he or she lives, but also within the global community. The first language and the state language(s) are significant for a learner, especially as a child. When teaching languages, it is crucial to consider the curriculum carefully and include strategies for the best learning outcomes.

\section{Conclusion}

A language is not merely a means of communication, but also a basis for learning other disciplines. Therefore, sound linguistic skills are the foundation for a person's success in overall education. Integrated language didactics helps the quality of language education; it rests on a constructivist approach (cognition and metacognition). The success of education is determined by the chosen language integration model, as well as involving active learning where languages are learnt by children exploring, discovering, analyzing, explaining, and referring to their own experience. It is crucial to choose topics that are interesting for children and which encompass integrated development of, not only linguistic, but also social and other life skills.

According to the data of our empirical research that examined the reasons behind the choice of model for integrated language didactics and that for bilingual or language learning in the classes of other disciplines, depends mostly on the opinion of the local community, the language(s) learners speak, and the diversity of languages used in the living environment. The development of a pupil's skills in their first language has a positive effect on learning of other languages as well as the peculiarities of their first language (especially when the language of the school is not the first language of the pupil). It helps a child to develop an identity and to retain his or her culture and traditions. At the same time, children need to learn other languages (state and foreign languages) to establish relationships within the local community, and later for a high quality of life, including communicating and cooperating with people from other countries. Integrated language didactics helps not only with language education, but also with developing a pupil's cognitive, social, and cultural skills.

\section{References}

Abdallah, K. B. (2013). «Classe d'accueil» ou «classe dépotoir». La politique éducative en question ["Reception class" or "class of landfill". The question of educational policy]. / in Groux, D., Barthélémy, F. L'enseignement des langues étrangères face aux évolutions des systèmes éducatifs [Assessment of the changes in the education system foreign languages teaching]. Paris: l'Harmattan, 87-109.

Beacco, J. C. (2008). Les langues dans les politiques d'intégration des adultes migrants [Adult language policy for the integration of migrants]. Conseil de l'Europe. 
Beacco, J. C. (2013). Éthique et politique en didactique des langues. Autour de la notion de responsabilité [Languages didactics ethics and politics. Around the concept of responsibility]. Paris: Les Éditions Didier.

Belhadj Hacen, A. (2013). Former les enseignants à la diversité linguistique et culturelle [Teachers education for linguistic and cultural diversity]. / in Belhadj Hacen, A., Marin, B. Enseignement/apprentissage des langues et contextualisation. [Language training provision/Learning and Contextualization]. Paris: 1'Harmattan, 151-166.

Belhadj Hacen, A., \& Legros, D. (2009). Actes du colloque international «L'interculturel et l'enseignement des langues minoritaires en France» [Articles of the international Conference on "Interculturalism and the learning of languages of national minorities in France"]. / AMIFA, Hellemmes - Lille, 16-17 avril.

Belhadj Hacen, A., \& Legros, D. (2010). Actes du colloque international «Langues, cultures, enseignement-apprentissages, CECRL et mondialisation» [Articles on international Conference "Language, culture, teaching/learning, and globalisation"]. AMIFA, Hellemmes - Lille, 16-17 avril.

Benaicha, F. Z., \& Legros, D. (2009). L'effet du contexte linguistique et culturel sur les stratégies de traitement des informations et la construction de connaissances en contexte plurilingue et pluriculturel. [Languages and cultures in the context of information and knowledge management strategies in the context of multilingual and multicultural workplaces]. in Mélanges francophones [French blends], 4. Vol III, 2, Actes de la conférence annuelle à l'occasion des Journées de la Francophonie, VIème édition, Galaţi, 27-29 mars, 91-101.

Blanchet, P. (2007). Quels 'linguistes' parlent de quoi, à qui, quand, comment et pourquoi? Pour un débat épistémologique sur l'étude des phénomènes linguistiques [What the "experts" talk about what 's, what, when, how and why? Linguistic phenomena examination epistemological debate]. / in Blanchet, Ph., Calvet, L.-J. et Robillard, D. Un siècle après le Cours de Saussure, la linguistique en question, Carnets de l'Atelier de Sociolinguistique [A century after Saussure 's course, the question of linguistics, remote Sociolinguistics workshops]. No. 1, Lesclap-Université d'Amiens, 66 pages, version papier Paris: L'Harmattan.

Blanchet, P. (2010). «Postface: Pourquoi s'interroger sur les influences et les enjeux des contextes plurilingues sur les textes et les discours? Eléments pour une théorie de la pluralité linguistique» ["Afterword: why doubt/influences and impacts from the challenges of multilingualism double-faced marginalisation texts and contexts. Elements of theory of linguistic diversity"]. / in Blanchet, Ph., Kebbas, M. et Kara-Abbes A. Y. (éds), Influences et les enjeux des contextes plurilingues sur les textes et les discours [Impacts and challenges of the texts and discourses allows double-faced marginalisation]. Limoges: Lambert-Lucas, 193-200.

Borg, S. (2013). Les sciences du langage et la didactique des langues à la croisée des politiques linguistiques, éducatives et culturelles. Dimensions méthodologique, curriculaire et réticulaire à visée comparatiste [Languages and linguistic sciences didactics language policies, education and culture at a crossroads. Methodological framework for the curriculum and comparison]. / in Groux, D., Barthélémy, F. L’enseignement des langues étrangères face aux évolutions des systèmes éducatifs [Changes in the education system, evaluation of teaching foreign languages]. Paris: 1'Harmattan, 53-74.

Brohy, C. (éd.). (2002). L'enseignement bilingue dans/par/à travers la forêt [Bilingual education to/from/through the woods]. $=$ Zweisprachiger Unterricht im/mit dem Wald und durch den Wald: actes des $4{ }^{\text {èmes }}$ Rencontres des enseignant(e)s bilingues: Nyon, 20 et 21 janvier 2000 / éd. Neuchâtel: Institut de recherche et de documentation pédagogique (IRDP), 1-90.

Brohy, C., \& Gajo, L. (2008). L'enseignement bilingue: état de situation et propositions. Vers une didactique intégrée [Bilingual education: situation and proposals. Towards an integrated didactics]. Conférence inter cantonale de l'instruction publique de la Suisse romande et du Tessin.

Bronckart, J. P., Bulea, E., \& Pouliot, M. (2005). Pourquoi et comment repenser l'enseignement des langues ? [Rethinking language education on why and how?] / in Bronckart, J.-P., Bulea, E., Pouliot, M. Repenser l'enseignement des langues: comment identifier et exploiter les compétences. [Rethinking language education: how to identify and develop competencies]. France: Presses Universitaires du Septentrion, 7-40.

Castellotti, V. (2013). L'articulation recherche-intervention en didactique des langues: comment (ne pas) en sortir? [Common language didactics intervention studies: how (not) to perform?] / in Beaucco, J.-C. Éthique et politique en didactique des langues. Autour de la notion de responsabilité [Language didactics ethics and politics. Around the concept of responsibility]. Paris: Les Éditions Didier, 74-98.

Chomentowski, M. (2009a). Enfants de migrants et échec scolaire: les aléas de l'apprentissage d'une langue seconde non médiatisée [Children of migrants and esl: opportunities to learn a second language undisclosed]. Paris: l'Harmattan. 
Chomentowski, M. (2009b). L'échec scolaire des enfants de migrants: l'illusion de l'égalité [Migrant children in school failure: the equality illusion]. Paris: l'Harmattan.

Cole, M. (1985). The zone of proximal development: Where culture and cognition create each other. / In Wertsch J. V. (Ed.) Culture, communication and cognition. Vygotskian perspectives. Cambridge: Cambridge University Press, 126-181.

Cortier, C., \& Di Meglio, A. (2004). L'enseignement du français langue régionale en Corse. Scolarisation des enfants migrants et rapport à l'autre [French language training in the region of Corsica. Migrant children and education]. / in Éducation et Sociétés Plurilingues [Education and multilingual Communities], 17, 73-86.

Coste, D. (2001). De plus d'une langue à d'autres encore. Penser les compétences plurilingues? [From one language for another. Think about multilingual competencies?] / in Castellotti V. D'une langue à d'autres: pratiques et représentations [From one language into another: practices and presentations]. Publications de l'Université de Rouen, Collection Dyalang, 191-202.

Coste, D. $\left(2002^{\mathrm{a}}\right)$. Compétence à communiquer et compétence plurilingue [Communicative competence and competence in multilingualism]. / Notions en Questions [The questions of concept], 6, 115-123.

Coste, D. (2002 $\left.{ }^{b}\right)$. Quelle(s) acquisition(s) dans quelle(s) classe(s)? [What is (are) achievement (- s) which (who) grade (- ies)?] / in AILE, 16, 3-22.

Coste, D. (2003). Construire des savoirs en plusieurs langues. Les enjeux disciplinaires de l'enseignement bilingue [Construction of knowledge of languages. Pertinent bilingual education]. Lyon: École normale supérieure Lettres et Sciences humaines. [Web blog post]. Retrieved from http://www.adeb.asso.fr/publications_adeb/Coste_Santiago_oct03.pdf

Coste, D. (2004). De quelques déplacements opérés par la notion de compétence plurilingue [A number of policies to the concept of multilingual expertise]. / in A. Auchlin et al. Structures et discours. Mélanges offerts à Eddy Roulet [Structure and discourses. Eddy Roulet offered mixtures]. Québec: Nota Bene, 67-85.

Coste, D. (2008). Éducation plurilingue et langue de scolarisation [A multilingual education and language learning]. / Cahiers de l'ACEDLE, volume V, 91-107. [Web blog post]. Retrieved from http://acedle.org/spip.php?article1011

De Pietro, J. F. (2003). La diversité au fondement des activités réflexives [The diversity background of business philosophy]. Repères No 28, 161-185.

Dolz, J., \& Schneuwly, B. (1997). Les genres scolaires. Des pratiques scolaires aux objets d'enseignement [School genres. School practices for training purposes]. / in Repères [Guidelines], 15, 27-40.

Dolz, J., \& Schneuwly, B. (1998). Pour un enseignement de l'oral. Initiation aux genres formels à l'école [For the speech learning. Introduction to the formal genres at school]. Paris: ESF.

Dolz, J., \& Thévenaz-Christen, T. (2002). Expliquer en didactique du français: réflexions à partir de recherches sur la planification textuelle [Explain the French language didactics: text planning philosophy studies]. / in Leutenegger, F., SaadeRobert, M. Expliquer et comprendre en sciences de l'éducation [To explain and understand the educational sciences]. Bruxelles: De Boeck, 88-110.

Dolz, J., Rosat, M.-C., \& Schneuwly, B. (1991). Elaboration et évaluation de deux séquences didactiques relatives à trois types de textes [Development and evaluation of two series of three texts didactics types]. / in Le français aujourd'hui [French language today], 93, 37-47.

Gajo, L., \& Grobet, A. (2011). Saturation des savoirs et variété des enseignements bilingues [Bilingual education, knowledge, diversity and saturation]. / in Berthaud, A.-C., Gradoux, X., Steffen, G. Plurilinguismes et construction des savoirs [Multilingualism and knowledge construction]. Lausanne: Centre de Linguistique et des Sciences du Langage, Cahiers de l'ILSL, N. 30, 71-94.

Hagège, C. (2005). Combat pour le français: Au nom de la diversité des langues et des cultures [Fight for French language: linguistic and cultural diversity]. Paris: Odile Jacob.

Hall, J. K. (1993). The role of oral practices in the accomplishment of our everyday lives: The sociocultural dimensijon of interaction with implications for the learning of another language. / in Applied Linguistics, 14/2, 145-167.

Kroll, J. (2010). Cognitive Benefits of Bilinguism. Pennsylvania State University.

Lantolf, J. P. (Ed.) (2000). Sociocultural theory and second language learning. Oxford: Oxford University Press.

Lantolf, J. P., \& Pavlenko, A. (1995). Sociocultural theory and second language acquistion. / in Annual Review of Applied Linguistics, 15, 180-124. 
Lave, J., \& Wenger, E. (1988). Situating learning: legitimate peripheral participation. Cambridge: Cambridge University Press.

Livre blanc sur le dialogue interculturel. «Vivre ensemble dans l'égale dignité» [White Paper on Intercultural Dialogue. "Living together as equals in dignity"]. (2008). Strasbourg: Conseil de l'Europe. [Web blog post]. Retrieved from http://www.coe.int/t/dg4/intercultural/source/white\%20paper_final_revised_fr.pdf

Martinand, J. L. (1986). Connaître et transformer la matière. [Thing's knowledge and transformation]. Berne: Peter Lang.

Maurer, B. (2011). Enseignement des langues et construction européenne. Le plurilinguisme, nouvelle idéologie dominante. [Language education and European construction. Multilingualism, the new dominant ideology]. Paris: Éditions des Archives contemporaines.

Moirand, S. \& Tréguer-Felten, G. (2007). Des mots de la langue aux discours spécialisés, des acteurs sociaux à la part culturelle du langage: raison et conséquences de ces déplacements [Specialized discourse words, social actors - language culture: causes and consequences of such movements]. / in ASP, 51-52, 7-33.

Mondada, L., \& Pekarek, S. (2000). Interaction sociale et cognition située: quels modèles pour la recherche sur l'acquisition des langues? [Social interaction and the situation of the enlightenment: what language development research models?] / in Acquisition et Interaction en Langue Étrangère [Foreign language acquisition and interaction], 12, 149-176.

Mondada, L., \& Pekarek, S. (2004). Second language acquisition as situated practice. / in The Modern Language Journal, $88 / 4$.

Moore, D., \& Castellotti, V. (2008). La compétence plurilingue. Regards francophones. [Plurilingual competence. French glances]. Berne: Peter Lang, Collection Transversales.

Puren, Ch. (2003). Pour une didactique comparée des langues-cultures [On comparative languages-cultures didactics]. / ELA Nr. 129. Paris, janvier-mars, 121-126.

Puren, Ch. (2004). De l'approche par les tâches à la perspective co-actionnelle [Approach to the job prospects for action]. in Les Cahiers de l'APLIUT (revue de l'Association des Professeurs de langues des Instituts de Technologie), 23(1), 10-26.

Rogoff, B. (1990). Apprenticeship in thinking: Cognitive development in social context. New York: Oxford University Press. Schubauer-Leoni, M. L., \& Dolz, J. (2004). Comprendre l'action et l'ingéniosité didactique de l'enseignant: une composante essentielle de la transformation de l'école [The teacher 's understanding and teaching innovatornes: an essential component of the school' s transformation]. / in Bronckart, J.-P., Gather Thurler, M. (Ed.) Transformer l'école. [Transforming school]. Bruxelles: De Boeck, 147-168. 